Doi: https://doi.org/10.24036/jep/vol4-iss1/443

\title{
Kemampuan Komunikasi Matematis Siswa SMP Melalui ELPSA Framework
}

\author{
Dessy Amalia, Rahmah Johar*, M. Ikhsan \\ Universitas Syiah Kuala \\ rahmah.johar@unsyiah.ac.id
}

\begin{abstract}
The mathematical communication ability of students is still low. One effort that can be done is to implement Experiences, Language, Pictures, Symbols, Application (ELPSA) framework. The pur pose of this research was to determine students' mathematical communication skills through the application of the ELPSA framework. This research is a descriptive quantitative research. The sub jects were Year 8 students of one of Junior High School in Banda Aceh which consisted of 24 students. Data collection is done through stdeunts worksheet and mathematical communication tests. Data ana lysis was performed by calculating the score of students' mathematical communication in groups and individually using percentage techniques. The results of this research are the mathematical com munication abilities of students in groups during learning with the implementation of ELPSA framework producing high average score. Whereas students' mathematical communication skills after the implementation of the ELPSA framework showed $75 \%$ of students met the minimal criteria.
\end{abstract}

Keywords : Mathematical communication, Circle, ELPSA framework

This is an open access article distributed under the Creative Commons 4.0 Attribution License, which permits unrestricted use, distribution, and reproduction in any medium, provided the original work is properly cited. $@ 2020$ by author and Universitas Negeri Padang.

\section{PENDAHULUAN}

Prestasi siswa Indonesia berdasarkan hasil PISA (Programme for International Students Assessment) tahun 2015 berada pada peringkat 64 dari 72 negara peserta (OECD, 2016). Se dangkan pada tahun 2018 siswa Indonesia bera da pada peringkat 74 dari 79 negara peserta (OECD, 2019). Hasil penelitian Putri (2015) me nemukan bahwa konten change and relationship pada soal PISA sesuai dengan indikator kemam puan komunikasi matematis. Oleh sebab itu, sa lah satu kompetensi yang diperlukan untuk me nyelesaikan soal yang diujikan di kancah Inter nasional tersebut adalah komunikasi matematis.

Komunikasi merupakan bagian yang esen sial dari matematika dan pendidikan matematika (NCTM, 2000). Simanjuntak (2014) menyata kan bahwa kemampuan komunikasi matematis harus ditingkatkan, karena peningkatan komuni kasi matematis siswa sangat berpengaruh dalam kemampuan siswa memahami matematika dan minat siswa dalam menguasai materi pelajaran matematika. Dengan demikian, diantara kemam puan yang harus dimiliki siswa salah satunya adalah kemampuan komunikasi matematis. Me nurut Yeager (Izzati \& Suryadi, 2010), kemam puan komunikasi matematis meliputi kemam puan dalam mengekspresikan matematika baik secara visual, lisan, maupun tulisan dalam baha sa matematika yang sesuai dan menggunakan kaidah-kaidah yang terdapat dalam matematika.
Meskipun disadari bahwa kemampuan komuni kasi matematis merupakan hal yang essensial na mun pencapaian kemampuan ini masih rendah akibat kurangnya perhatian guru dalam pengem bangan kemampuan ini. Rendahnya kemampuan ini juga dinyatakan melalui hasil penelitian Iz zati dan Suryadi (2010), yaitu salah satu titik le mah dalam pembelajaran matematika adalah ber komunikasi matematik.

Menerapkan suatu kerangka pembelajaran yang mendukung berkembangnya kemampuan komunikasi matematis siswa merupakan salah satu upaya yang dapat dilakukan guru guna me ningkatkan kemampuan ini. Salah satu kerangka pembelajaran yang sesuai adalah ELPSA frame work. ELPSA terdiri dari (Experiences, Langua ge, Pictures, Symbols, Application). Dalam pem belajaran dengan menerapkan ELPSA frame work siswa dituntut untuk membangun sendiri pemahamannya melalui proses berfikir secara individu dan berinteraksi dengan temannya. ELP $S A$ framework dikembangkan untuk Indonesia secara khusus berdasarkan analisis dari video TIMSS (Lowrie \& Patahuddin, 2015a).

ELPSA framework ini memuat lima kom ponen. Komponen tersebut adalah 1) Experience (pengalaman); 2) Language (bahasa yang menje laskan pengalaman); 3) Pictorial (gambar yang mempresentasikan pengalaman); 4) Symbol (sim bol tertulis yang mengekspresikan pengalaman secara umum); dan 5) Application (aplikasi yang 
berhubungan dengan bagaimana pengetahuan yang telah diperoleh dapat diterapkan dalam ber bagai macam situasi). Kerangka pembelajaran ELPSA cukup menjanjikan dalam meningkatkan kualitas pembelajaran matematika di Indonesia, (Lowrie \& Patahuddin, 2015 a). Nurhalimah (2016) menemukan bahwa pada soal berfikir kreatif penerapan ELPSA framework menjadi kan kemampuan siswa dalam menyampaikan ja wabannya secara matematis berkembang. Pene litian lainnya yang dilaksanakan Johar dan Hajar (2016) memperlihatkan ELPSA framework mem berikan kesempatan yang banyak kepada siswa untuk dapat mengkomunikasikan ide-ide mate matisnya. Meskipun demikian belum ditemukan penelitian yang menganalisis kemampuan komu nikasi matematis siswa dengan menerapkan ELP $S A$ framework. Dengan demikian, rumusan masa lah pada penelitian ini adalah bagaimanakah kemampuan komunikasi matematis siswa SMP secara berkelompok dan secara individu melalui penerapan ELPSA framework?

\section{METODE PENELITIAN}

Penelitian ini termasuk penelitian kuantita tif deskriptif yang bertujuan untuk mendeskripsi kan kemampuan komunikasi matematis siswa berdasarkan indikator-indikator komunikasi ma tematis. Adapun yang menjadi subjek pada pene litian ini adalah siswa kelas VIII SMP IT Nurul Ishlah Banda Aceh tahun Pelajaran 2016/2017 sebanyak satu kelas dengan 24 orang siswa. Ke las tersebut dipilih berdasarkan hasil wawancara dengan guru di sekolah tersebut. Ditemukan bah wa kemampuan siswa dalam menyelesaikan soal soal komunikasi matematis masih belum maksi mal. Adapun pertimbangan diambilnya subjek penelitian pada kelas VIII disebabkan siswa pada kelas tersebut berusia 13-14 tahun yang menurut teori perkembangan Piaget (Suparno, 2001), siswa MTs/SMP (usia 11-15 tahun) telah memasuki fase operasi formal, pada tahap ini anak sudah bisa berpikir logis, berpikir dengan menggunakan pemikiran teoritis formal berdasar kan proposisi dan hipotesis, dan bisa mengambil kesimpulan.

Pada penelitian ini salah satu penulis terli bat sebagai guru. Pembelajaran dilakukan dalam empat pertemuan. Materi yang diajarkan secara adalah unsur-unsur pada lingkaran; keliling dan luas lingkaran; hubungan antara sudut pusat de ngan sudut keliling lingkaran; dan panjang busur serta luas juring lingkaran. Perangkat pembela jaran pada penelitian ini terdiri dari Rencana Pelaksanaan Pembelajaran (RPP), Lembar Kerja Peserta Didik (LKPD), dan tes. Perangkat yang dikembangkan divalidasi oleh tiga orang pakar yaitu satu orang dosen dari pendidikan matema tika UIN Ar-Raniry, satu orang dosen dari pen didikan matematika STKIP BBG Banda Aceh yang memahami komunikasi matematis, dan sa tu orang guru yang pernah mengikuti pelatihan pada ELPSA conference di IKIP Mataram serta pernah mengembangkan perangkat pembelajar an ELPSA framework. Berdasarkan hasil valida si dilakukan beberapa perbaikan. Secara keselu ruhan, semua validator menyatakan perangkat pembelajaran sudah bisa digunakan.

Instrumen pada penelitian ini adalah seper ti berikut.

1. LKPD yang diberikan selama tiga pertemuan untuk mengetahui kemampuan komunikasi matematis siswa selama pembelajaran. Siswa mengerjakan LKPD secara berkelompok lalu di akhir LKPD diberikan soal yang juga dikerjakan secara berkelompok. Soal pada LKPD untuk setiap pertemuan memuat indi kator kemampuan komunikasi matematis

2. Soal tes kemampuan komunikasi matematis siswa. Soal ini dikerjakan secara individu yang diberikan setelah penerapan ELPSA framework. Soal terdiri dari empat soal essay yang memuat tiga indikator komunikasi mate matis. Indikator tersebut adalah menjelaskan ide dan situasi secara tulisan, menyatakan gambar atau diagram ke dalam ide-ide mate matika, menyatakan situasi ke dalam model matematika/gambar (NCTM, 2000). Selanjut nya, kemampuan komunikasi matematis dia nalisis untuk setiap indikator

Analisis kemampuan komunikasi matema tis mengacu pada rubrik penskoran kemampuan komunikasi matematis dengan skor 0, 1, 2, 3, 4 .

Tabel 1. Kriteria Nilai Kemampuan Komunikasi Matematis

\begin{tabular}{|l|c|c|}
\hline No & Persentase Nilai & Kriteria \\
\hline 1 & $90 \%<\mathrm{x} \leq 100 \%$ & Sangat Tinggi \\
\hline 2 & $80 \%<\mathrm{x} \leq 90 \%$ & Tinggi \\
\hline 3 & $65 \%<\mathrm{x} \leq 80 \%$ & Sedang \\
\hline 4 & $55 \%<\mathrm{x} \leq 65 \%$ & Rendah \\
\hline 5 & $\mathrm{x} \leq 55 \%$ & Sangat Rendah \\
\hline \multicolumn{3}{|c}{ Nurkancana dan Sunarta $(1986: 80)$}
\end{tabular}

Selanjutnya, jumlah skor yang diperoleh dibagi dengan skor ideal lalu dikali 100\% sehingga di peroleh nilai kemampuan komunikasi matematis siswa. Adapun kriteria nilai tersebut dikelompok 
kan berdasarkan Nurkancana dan Sunarta (1986: 80) seperti terlihat pada Tabel 1. Selanjutnya, di hitung persentase banyaknya siswa yang meme nuhi Kriteria Ketuntasan Minimal (KKM) di se kolah tersebut, yaitu 75 .

\section{HASIL DAN PEMBAHASAN}

\section{Kemampuan Komunikasi Matematis Siswa Secara Berkelompok}

Nilai kelompok dalam mengerjakan soal komunikasi matematis pada LKPD untuk setiap pertemuan dapat dilihat pada Tabel 2.

Tabel 2. Nilai Kelompok Dalam Menyelesaikan Soal Komunikasi Matematis

\begin{tabular}{|c|c|c|c|c|}
\hline \multirow{2}{*}{ Kelompok } & \multicolumn{3}{|c|}{ LKPD } & \multirow{2}{*}{$\begin{array}{c}\text { Rata- } \\
\text { rata }\end{array}$} \\
\cline { 2 - 4 } & $\mathbf{1}$ & $\mathbf{2}$ & $\mathbf{4}$ & 81.9 \\
\hline I & 83.3 & 62.5 & 100 & 97.2 \\
\hline II & 91.7 & 100 & 100 & 90.3 \\
\hline III & 83.3 & 87.5 & 100 & 91.7 \\
\hline IV & 75 & 100 & 100 & 88.9 \\
\hline V & 91.7 & 87.5 & 87.5 & \\
\hline Rata-rata & 85 & 87.5 & 97.5 & \\
\hline
\end{tabular}

Pada pertemuan pertama, rata-rata nilai kelompok dikategorikan tinggi. Akan tetapi ada satu kelompok yang nilainya paling rendah yaitu kelompok IV. Hal ini dikarenakan kelompok IV salah dalam menyebutkan persamaan antara dia meter dan jari-jari lingkaran. Mereka menyata kan bahwa persamaan antara diameter dan jarijari adalah "Sama-sama tegak lurus". Berikut jawaban kelompok IV untuk soal pada LKPD I.

\begin{tabular}{|c|c|}
\hline $\begin{array}{l}\text { Jawablah soal beríkut } \\
\text { 1. Sebutkan persamaan dan perbedaan }\end{array}$ & Íní! \\
\hline $\begin{array}{l}\text { (1) X Persamaan } \\
\text { - Sama' tegak lurus } \\
\text { - Sama" berada dalam daerah lingkaran }\end{array}$ & 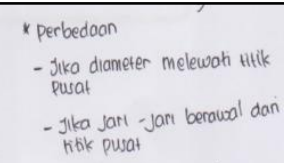 \\
\hline (2.) Iebih panjang diameter, karena diameter & membogi 2 lingkaran 3 \\
\hline
\end{tabular}

Gambar 1. Jawaban Kelompok IV LKPD 1

Pada saat mengerjakan LKPD guru telah membimbing siswa. Namun kurang tepatnya ja waban siswa luput dari perhatian guru. Pada per temuan kedua rata-rata nilai kelompok siswa dalam menyelesaikan tugas LKPD 2 juga dikate gorikan tinggi. Siswa mengerjakan LKPD 2 ten tang luas dan keliling lingkaran. Pada pertemuan ini, kelompok IV yang pada pertemuan pertama memperoleh nilai paling rendah mengalami per kembangan. Sedangkan nilai kelompok I menga lami penurunan dibanding pertemuan sebelum nya. Mereka salah pada saat mengerjakan soal nomor 2. Untuk soal nomor 2 siswa diberikan dua lingkaran dengan ukuran yang berbeda, sete lah itu siswa diminta untuk menentukan keliling yang lebih besar. Berikut merupakan jawaban da ri kelompok I pada LKPD 2.

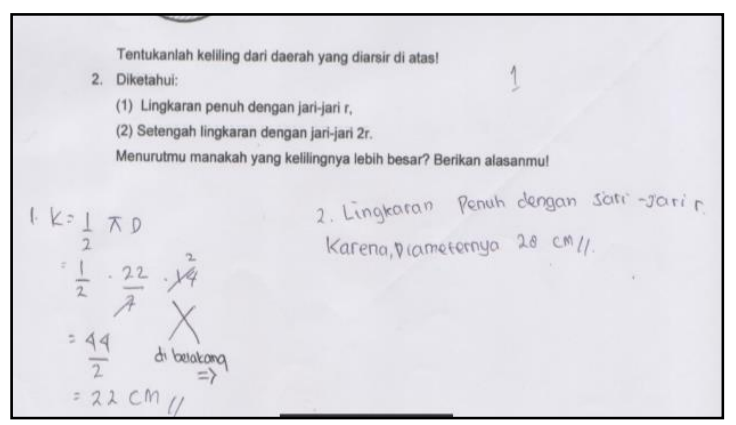

Gambar 2. Jawaban Kelompok I LKPD 2

Kelompok I tidak menentukan jawaban berdasarkan konsep menemukan keliling, tetapi mereka hanya melihat dari jari-jari lingkaran dan mereka mengira soal nomor 2 menggunakan gambar yang diberikan pada soal nomor 1 . Hal ini dapat dilihat melalui rekaman video pembela jaran, berikut cuplikan percakapan kelompok I saat mengerjakan LKPD 2.

Siswa1: Soal nomor 2 kayak mana (bagaima na)? Apa pakai yang ini (menunjuk soal nomor 1$)$ ?

Siswa2: Soalnya, manakah yang kelilingnya le bih besar, yang ini kan yang " $r$ ".

Siswa3: Coba liat dulu, lingkaran penuh jarijari " $r$ " dan setengah lingkaran jari-jari " $2 r$ ", hmm yang ini. (menunjuk ling karan penuh dengan jari-jari " $r$ ")

Dari percakapan tersebut terlihat bahwa mereka tidak menentukan jawaban mengguna kan konsep keliling yang benar, mereka hanya melihat berdasarkan bentuk lingkaran. Selain kelompok I terdapat satu kelompok lagi yang nilainya menurun yaitu kelompok $\mathrm{V}$, namun demikian nilai yang diperoleh kelompok $\mathrm{V}$ pada LKPD 2 ini masih dalam kategori tinggi. Pada LKPD 2 terdapat satu kelompok yang kemam puan komunikasi matematisnya dikategorikan rendah, dua kelompok yang kemampuan komu nikasi matematisnya tinggi, dan dua kelompok lagi dikategorikan sangat tinggi.

Pada pertemuan ketiga siswa diberikan pembelajaran menemukan hubungan antara 
sudut pusat dan sudut keliling, rumus untuk men cari panjang busur, serta luas juring lingkaran. Siswa tidak diminta menjawab soal, sehingga tidak ada nilai LKPD untuk pertemuan ini. Pada pertemuan keempat siswa kembali mengerjakan soal-soal komunikasi matematis mengenai pan jang busur dan luas juring lingkaran. Rata-rata nilai kelompok siswa pertemuan keempat pada LKPD 4 dikategorikan sangat tinggi. Pada perte muan ini siswa sudah mulai terbiasa dengan pem belajaran dengan penerapan ELPSA framework dan siswa juga sudah terbiasa dalam mengerja kan soal-soal komunikasi matematis.

Secara keseluruhan nilai yang diperoleh untuk masing-masing kelompok pada tiap-tiap LKPD adalah sangat baik dengan rata-rata nilai nya 90. Nilai tertinggi diperoleh oleh kelompok II dan yang terendah diperoleh oleh kelom pok I. Jika dilihat saat diskusi, tiap-tiap anggota kelom pok II terlihat lebih aktif dalam mengutarakan pendapatnya. Hal ini menunjukkan bahwa siswa mengikuti dengan baik setiap tahap pada ELP $S A$. Sehingga siswa lebih mudah dalam menyele saikan soal-soal yang diberikan pada tahap $A p$ plication. Pada kelompok I tampak bahwa hanya dua siswa yang aktif dalam berdiskusi, sedang kan anggota lainnya terlihat pasif dan hanya kadang-kadang memberikan pendapat.

\section{Kemampuan Komunikasi Matematis Siswa Secara Individu}

Berdasarkan hasil tes akhir, nilai komuni kasi matematis untuk seluruh siswa setelah dite rapkan ELPSA Framework dapat dilihat pada Tabel 3. Dari tabel dapat disimpulkan bahwa terdapat 18 siswa (75\%) yang mencapai KKM. Kemampuan komunikasi matematis siswa pada tiap-tiap indikator komunikasi matematis dijelas kan seperti berikut.

1. Indikator menyatakan situasi ke dalam model matematika/gambar

Berdasarkan Tabel 3, siswa yang dapat menjawab soal dengan tepat adalah 18 orang dari 24 siswa. Hal ini terlihat dari tepatnya siswa dalam memahami maksud dari soal, kejelasan gambar dan kelengkapan alasan yang diberikan. Sedangkan enam orang siswa memberikan gam bar yang benar tetapi keterangan atau penjelasan gambar tidak dituliskan. Dapat disimpulkan bah wa umumnya siswa sudah memenuhi kemam puan pada indikator menyatakan situasi ke da lam model matematika/gambar. Adapun salah satu jawaban siswa dapat dilihat pada Gambar 3.
Tabel 3. Nilai Komunikasi Matematis Seluruh Siswa

\begin{tabular}{|c|l|c|c|}
\hline No & Siswa & Nilai & Ketuntasan \\
\hline 1 & AF & 75 & Tuntas \\
\hline 2 & AF & 43,75 & Tidak Tuntas \\
\hline 3 & AS & 93,75 & Tuntas \\
\hline 4 & CN & 100 & Tuntas \\
\hline 5 & CR & 62 & Tidak Tuntas \\
\hline 6 & DZ & 56,25 & Tidak Tuntas \\
\hline 7 & FA & 87,5 & Tuntas \\
\hline 8 & HF & 81,25 & Tuntas \\
\hline 9 & KK & 100 & Tuntas \\
\hline 10 & LJ & 81,25 & Tuntas \\
\hline 11 & LK & 93,75 & Tuntas \\
\hline 12 & MM & 81,25 & Tuntas \\
\hline 13 & NS & 87,5 & Tuntas \\
\hline 14 & NA & 75 & Tuntas \\
\hline 15 & NT & 81,25 & Tuntas \\
\hline 16 & NZ & 56,25 & Tidak Tuntas \\
\hline 17 & PA & 87,5 & Tuntas \\
\hline 18 & QA & 75 & Tuntas \\
\hline 19 & RL & 43,75 & Tidak Tuntas \\
\hline 20 & RR & 93,75 & Tuntas \\
\hline 21 & SA & 75 & Tuntas \\
\hline 22 & SF & 75 & Tuntas \\
\hline 23 & ST & 37,5 & Tidak Tuntas \\
\hline 24 & TS & 75 & Tuntas \\
\hline
\end{tabular}

Untuk menyelesaikan soal pada indikator menyatakan situasi ke dalam model matema tika/gambar, keberhasilan sebagian besar siswa dipengaruhi oleh pembelajaran yang telah mere ka ikuti, yaitu ELPSA Franework..

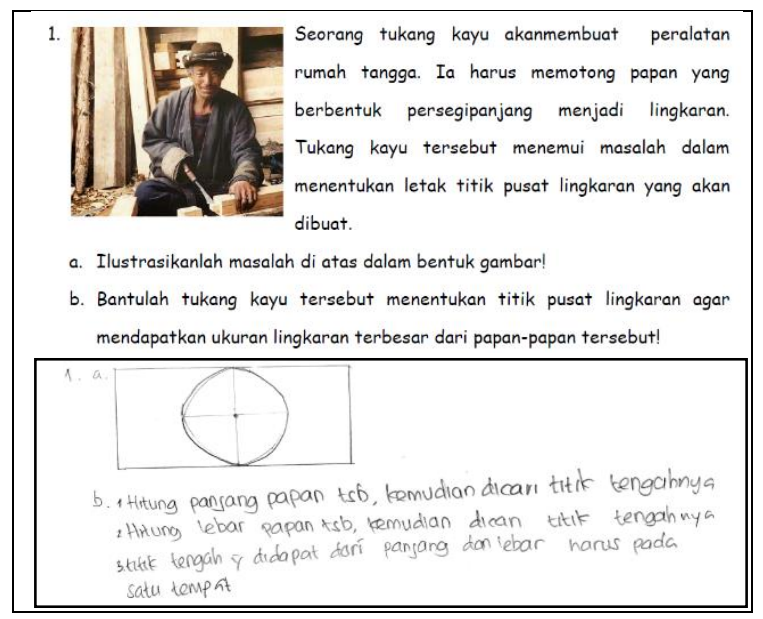

Gambar 3. Jawaban Salah Satu Siswa pada Indikator Menyatakan Situasi ke dalam Model Matematika/Gambar

Selama pembelajaran, siswa berdiskusi da lam kelompok. Diskusi ini terjadi pada kompo nen Language, Picture, Symbol, dan Applica tion. Melalui kegiatan diskusi pada keempat komponen tersebut siswa aktif menyampaikan 
pendapat sehingga pemahaman matematis mere ka menjadi lebih baik. Hal ini sesuai dengan hasil penelitian Martin, Towers, dan Pirie (2009) yang menemukan bahwa belajar melalui diskusi menyebabkan pemahaman matematis siswa menjadi lebih baik yang terlihat pada kemam puan mereka dalam menyelesaikan tugas mate matika.

2. Indikator menyatakan situasi atau ide-ide matematis ke dalam bahasa, simbol, dan model matematika

Untuk indikator ini, terdapat 8 orang sis wa yang memberikan jawaban dengan tepat. Siswa telah menggunakan bahasa yang baik kare na sistematis dan mudah dimengerti disertai ala san-alasan yang jelas. Contoh jawaban dari salah seorang siswa dapat dilihat pada Gambar 4.

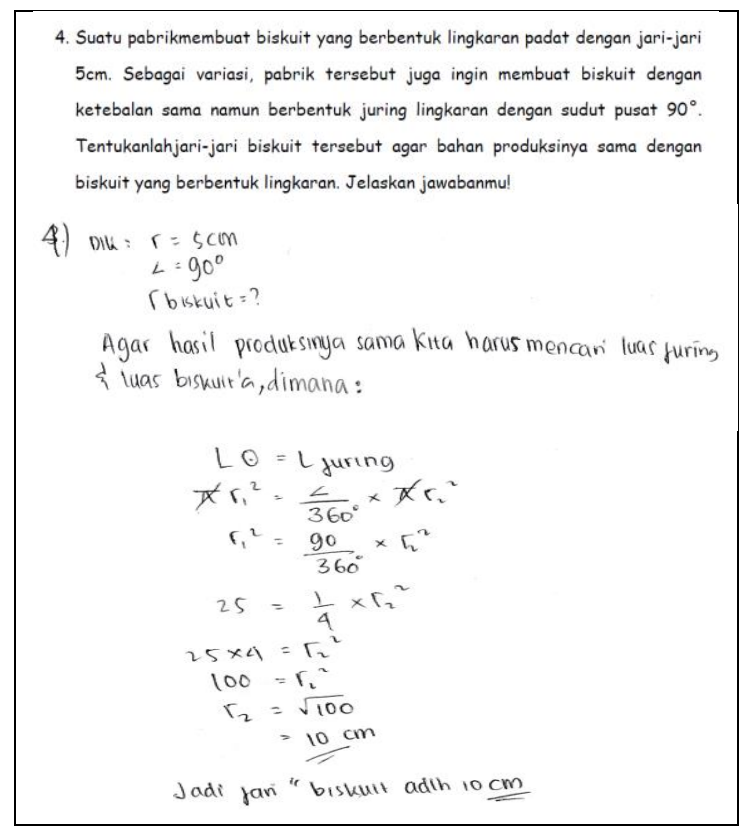

Gambar 4. Jawaban Salah Satu Siswa pada Indikator Menyatakan Situasi ke dalam Bahasa, Simbol, dan Model Matematika

Siswa yang memberikan jawaban kurang tepat ada 11 orang pada indikator ini. Ide penye lesaian soal yang diberikan oleh siswa sudah tepat tetapi mereka menjawab dengan bahasa yang sulit dimengerti dan tidak memberikan alasan yang logis. Hal ini berarti, siswa meng alami kesulitan dalam mengungkapkannya da lam bentuk tulisan, simbol dan model mate matika. Begitu pula untuk lima orang siswa lain nya. Jawaban yang diberikan oleh lima orang siswa tersebut tidak tepat bahkan ada yang tidak memberikan jawaban.

Pada indikator ini, kemampuan siswa un tuk menyelesaikan soal terkait dengan pene rapan ELPSA framework. Hal ini didasarkan pada rekaman video selama pembelajaran dan pengamatan ketika mengajar di kelas. Siswa yang dapat menyelesaikan soal dengan sangat baik adalah siswa yang aktif dalam pembela jaran. Mereka terlihat aktif di awal pembelajaran dalam memberikan respon terhadap pertanyaan yang diberikan oleh guru pada komponen $E x$ perience. Ini menunjukkan bahwa mereka mem punyai pemahaman awal yang baik. Selanjutnya, ketika kegiatan diskusi kelompok, yaitu pada komponen Language, Picture, dan Symbol siswa terlihat juga aktif. Dalam diskusi kelompok me reka terlihat sering menyampaikan pendapat maupun mengajukan pertanyaan, dan mem berikan bantuan kepada teman di kelompoknya dalam memahami dan menyelesaikan persoalan pada LKPD. Pada komponen Application siswa memperlihatkan kinerja yang baik. Inilah yang mendukung mereka untuk dapat menyelesaikan tes akhir secara individu dengan sangat baik. Dengan pembelajaran menggunakan ELPSA framework mereka terbiasa menyampaikan ideidenya dengan berbahasa sehingga memudahkan mereka menyelesaikan persoalan yang menuntut untuk menyampaikankan ide-ide matematisnya. Hasil ini sesuai dengan hasil penelitian yang dila kukan oleh Arifin (2015), yaitu bahasa berman faat dalam memahami masalah dan membantu mendeskripsikan pemahaman terhadap konsep tertentu dengan tepat.

Kesulitan dalam mengungkapkan ide-ide dalam bahasa, simbol, dan model matematika mempengaruhi kemampuan komunikasi mate matis siswa baik secara lisan maupun tulisan. Ini didukung oleh pernyataan Baroody (Ansari, 2012) bahwa komunikasi matematis meliputi lima aspek yaitu representasi, mendengar, mem baca, diskusi dan menulis.

Adanya kelemahan siswa berkaitan de ngan menyampaikan ide matematis yang merupa kan hasil temuan pada penelitian ini member kan rekomendasi kepada guru untuk menentu kan usaha yang akan digunakan untuk memban tu siswa dalam meningkatkan kemampuan mate matisnya. Guru diharapkan dapat membiasakan siswa menyelesaikan soal-soal non-rutin, salah satunya soal yang berkaitan dengan komunikasi matematis. Melalui komponen aplikasi pada $E L$ PSA framework guru dapat memperbanyak soal non rutin sehingga siswa terbiasa memyampai kan ide-ide matematisnya. Arifin (2015) menya takan bahwa pembelajaran dengan mengguna kan ELPSA framework memberi kesempatan 
kepada siswa mengkomunikasikan dengan meng gunakan bahasa untuk mendeskripsikan penga laman mereka, menyajikan pengalaman tersebut secara visual atau gambar, menyajikan generali sasi dengan menggunakan simbol, dan mengapli kasikan pengetahuan untuk menyelesaikan ma salah-masalah non-rutin dari berbagai konteks maupun situasi.

3. Indikator menyatakan gambar atau diagram ke dalam ide-ide matematika

Pada indikator ini, ada sebelas orang sis wa yang memberikan jawaban dengan sangat baik. Mereka dapat memahami gambar yang diberikan dan menyelesaikan permasalahan terse but secara jelas dan sistematis. Selanjutnya ada sepuluh orang siswa yang memberikan jawaban berdasarkan informasi pada soal tetapi masih ada kekeliruan yang dilakukan oleh siswa dalam memahami gambar dan perintah soal, kesalahan dalam menyelesaikan soal, dan kesalahan dalam melakukan perhitungan. Ada tiga orang siswa yang tidak dapat memberikan jawaban. Pada Gambar 5 dapat dilihat contoh salah satu ja waban dari siswa.

3. Tentukanlah keliling dari daerah yang diarsir berikut!
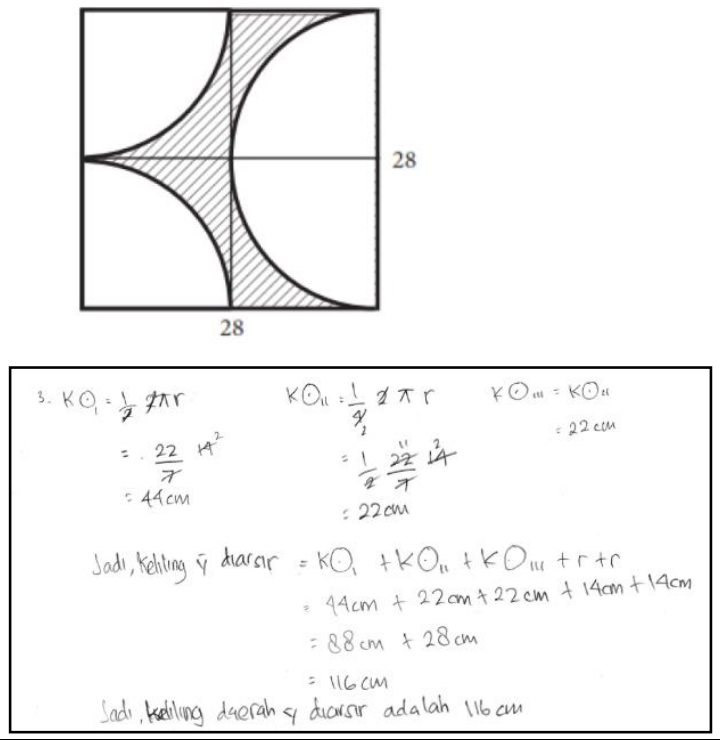

Gambar 5. Jawaban Salah Satu Siswa pada

Indikator Menyatakan Gambar ke dalam Ide-Ide Matematika

Kesalahan-kesalahan yang dibuat oleh siswa untuk menyelesaikan soal komunikasi matematis dalam indikator ini disebabkan oleh berbagai faktor. Faktor tersebut diantaranya ada lah mereka belum terbiasa dan kurang teliti da lam meyelesaikan soal tersebut. Ini dapat dilihat dari hasil rekaman video selama pembelajaran berlangsung dan pengamatan pada beberapa siswa yang terlihat pasif dalam menanggapi per tanyaan yang diberikan oleh guru mulai dari komponen Experience. Berdasarkan hasil wa wancara dengan beberapa orang siswa, terung kap bahwa mereka jarang mengulang pelajaran di rumah sehingga hal ini membuat mereka sering lupa tentang materi yang telah dipelajari sebagai pengetahuan prasyarat. Padahal kom ponen Experience ini merupakan komponen yang utama dalam pembelajaran karena apabila ide-ide matematika yang terkait dengan penge tahuan awal maka kebermaknaan konsep yang dipelajari dapat diperoleh (Widjaya, Fauzan \& Dolk, 2010). Akibat dari kekurang penguasaan siswa terhadap pengetahuan awal ini menyebab kan siswa pasif pada saat kegiatan diskusi kelom pok pada komponen berikutnya yaitu Language, Picture dan Symbol. Apalagi pada komponen application, mereka tidak dapat menyelesaikan soal-soal komunikasi tersebut dengan tepat. Hal ini didukung oleh pernyataan Flavel (Resnick, 1981) bahwa keterampilan yang diperoleh siswa pada permulaan belajar dapat mempengaruhi proses belajar selanjutnya karena belajar meru pakan suatu hirarki.

Beberapa orang siswa yang lainnya pada awal pembelajaran untuk komponen Experience terlihat tidak terlalu aktif dalam menanggapi pertanyaan yang diberikan oleh guru tetapi terlihat lebih aktif pada saat kegiatan diskusi kelompok untuk komponen Language, Picture, dan Symbol. Ini menyebabkan pemahaman mereka tentang konsep yang diajarkan guru menjadi lebih baik sehingga mereka dapat menyelesaikan soal-soal komunikasi matematis pada komponen Application dan tes individu. Untuk meningkatkan kemampuan komunikasi matematis siswa, guru harus selalu melaksana kan pembelajaran yang membuat siswa termoti vasi untuk belajar. Ini didukung oleh hasil pene litian yang dilaksanakan Rini (2016) menemu kan bahwa semakin tinggi motivasi belajar maka pemahaman konsep siswa juga semakin baik. Berkaitan dengan komunikasi matematis, Ansari (2009) menyatakan bahwa terdapat beberapa faktor yang mempengaruhi diantaranya pengeta huan prasyarat, kemampuan membaca, diskusi, dan menulis serta pemahaman matematis. Oleh karena itu guru dan peneliti berikutnya dapat menerapkan ELPSA Framework untuk materi matematika lainnya dan memperhatikan faktorfaktor yang mempengaruhi komunikais matema tis siswa. 


\section{KESIMPULAN}

Nilai rata-rata kemampuan komunikasi matematis siswa secara berkelompok dengan menerapkan ELPSA framework berada dalam kategori tinggi, sedangkan secara individu sete lah menerapkan ELPSA framework adalah 75\% siswa memenuhi kriteria ketuntasan minimal. Kemampuan komunikasi matematis siswa terse but adalah siswa 1) mampu menyajikan gambar disertai dengan penjelasan yang tepat, 2) mam pu memberikan jawaban dengan tepat, jelas, dan bahasa yang mudah dimengerti, dan 3) memaha mi gambar dengan baik dan mampu memberi kan jawaban berdasarkan informasi yang diberikan, dan disampaikan secara sistematis.

Disarankan kepada guru yang akan mene rapkan ELPSA framework untuk merancang ke giatan yang menarik dan menantang pada kom ponen experience sehingga siswa dapat menyele saikan dengan bahasa (language) mereka sen diri, menvisualkannya (pictorial), menamukan kesimpulan dalam bentuk simbol (symbol) dan menerapkannya (application) pada permasa lahan yang non-rutin.

\section{DAFTAR PUSTAKA}

Ansari, B. I. (2009). Komunikasi Matematika Konsep dan Aplikasi. Banda Aceh: Pena

Arifin. (2015). Lesson Plan Berbasis Kerangka Kerja ELPSA untuk Membangun Pema haman Konsep Penjumlahan dan Pengu rangan Bilangan Bulat pada Siswa.Jurnal Kependidikan, 14(1), 11-21.

Hajar, S., \& Johar, R. (2016). Implementation of ELPSA Framework in Teaching Integral Using Technology. International Journal of Science and Applied Technology, 1(1), 15-21.

Izzati, N., \& Suryadi, D. (2010). Komunikasi Matematik dan Pendidikan Matematika Realistik. Prosiding Seminar Nasional Matematika dan Pendidikan Matematika, 27, 721-729.

Kemendikbud. (2013). Kerangka Dasar dan Struktur Kurikulum 2013. Jakarta: Kemen dikbud.

Lowrie, T., \& Patahuddin, S.M. (2015a). ELP SA - Kerangka Kerja untuk Merancang Pembelajaran Matematika. Jurnal Didak tik Matematika, 2(1), 2-6.
Lowrie, T.,\& Patahuddin, S.M. (2015b). ELP SA as a Lesson Design Framework. Jour nal of Mathematics Education, 6(2), 1-15.

Lowrie, T., Patahuddin, S.M., \& Ihsan (2015). Pola Bilangan dan Pengajaraannya: Penggunaan Kerangka ELPSA. Australia: University of Canberra. Dipresentasikan pada workshop ELPSA di University of Canberra dan IKIP Mataram, NTB pada tanggal 24 Februari 2015.

Martin, L., Towers, J., \& Pirie, S. (2009). Collective Mathematical Understanding as Improvisation. International Journal Mathematical Thingking and Learning, 8(2), 149-183.

NCTM. (2000). Principles and Standards for School Mathematics. Reston, VA: NCTM

Nurhalimah. (2016). Perkembangan Berfikir Kreatif dan Disposisi Matematis Siswa melalui ELPSA Framweork di SMP. Tesis Magister. Tidak diterbitkan, Universitas Syiah Kuala.

Nurkancana, Wayan, \& Sunarta. (1986). Eva luasi Pendidikan. Surabaya: Usaha Nasio nal

OECD. (2016). PISA 2015 Results in Fokus. New York: Columbia University

Resnick, L.B., \& Ford, W. W. 1981. The Psychology of Mathematics for Instruc tion. University of Pittsburgh

Rini, E.S. (2016). Pemahaman Konsep dan Motivasi Belajar Matematika Siswa kelas X Madrasah Aliyah Negeri 1 Palu Melalui Model Pembelajaran Berbasis Masalah dan Model Pembelajaran Inkuiri. EJurnal Mitra Sains, 4(2), 20-29.

Simanjuntak, M. (2014). Peningkatan Kemam puan Representasi dan Komunikasi Matematis Siswa SMP pada Materi Transformasi dengan Strategi Think-TalkWrite (TTW) Berbantuan Kartu Domino di Kelas VII SMP Negeri 3 Tebing Tinggi. Tesis Magister. Tidak diterbitkan, Univer sitas Negeri Medan.

Widjaja, W., Fauzan, A., \& Dolk, M. (2010). The role of context and teacher's questioning to enhance students' thing king. Journal of Science and Mathematics Education in Southeast Asia, 33(2), 168186. 